\title{
Study on Spiritual Effect of Memory, Related To Neural Science on Students of Professional Institutes at Indian Bop Segment
}

\author{
${ }^{1}$ Prof. (Dr.) Bhudhar Ranajan Chatterjee, ${ }^{2}$ Prof. (Dr.) Archana Lala \\ Associate-Prof / Head, Dept. of Management, Director, S R Group of Institutes, Ambabai, Jhansi-284002, \\ $U P$, India.
}

\begin{abstract}
Anatomical analysis of Human Memory based on Neural Science, remains an area of great interest for scientists, from time immemorial.

The current research may be a Pioneering effort in the area of religious traits of a student at the BOP segment and his capacity to learn. Students aspiring for Professional Education, such as Engineering, Management, belonging to low and mid-income group, are a confused lot. As many Researchers (Jaywalk, Karnani) vehemently argued, whether OPPORTUNITY really exits at the Bottom or Mid of the Pyramid, is of another issue and research, the present Research would endeavor to focus on the mid level of our society.

C. K. Prahalad conceptualized and vehemently propagated BOP and stated that there lies a huge market of billions of people in Emerging Markets as potential customer, who earns less than $\$ 2$ a day. Prof. Prahalad also advocated as -we must stop thinking that these billion people are a drag on our economy, rather they are resilient and value-conscious consumers and an unforeseen door of opportunity may be opened. Creating Leaders at the BOP level through various successful experiments by ITC / AMUL/ JAIPUR RAGS / SHAKTI AMMAS - HLL/ICICI BANK -SHG and so on, are there in India. This Co-creation of Leadership culture has made a huge difference in Socio-economic fabric of rural India.

Researchers, in this paper, would endeavor to find out empirically, if there is any Co-relation, between Spiritual effects on Student-mind and Memory at BOP segment in India.

Keywords: Anatomical, Neural, BOP, Opportunity.
\end{abstract}

\section{Overview}

The analysis of the anatomical and physical bases of learning and memory, is one of the great successes of modern neuroscience. Thirty years ago little was known about how memory works, but now we know a great deal. There are a no of discussion on four issues that are central to learning and memory. First, what are the different types of memory? Second, where in the brain is memory located? One possibility is that human memory is similar to the memory chip in a personal computer (PC), which stores all the memory in one location. A second possibility is that our memories are distributed and stored in different regions of the brain. Third, how does memory work? What types of changes occur in the nervous system when a memory is formed and stored, are there particular genes and proteins that are involved in memory, and how can a memory last for a lifetime? Fourth, is the issue of importance to many people, especially as we age: How can memory be maintained and improved, and how can it be fixed when it is broken Much of what has been learned about the neural and molecular mechanisms of learning and memory have come from the use of so called "Model System".

The activities of Neurons, behavior of a particulars genes and proteins and related effect on Memory or Learning are the domains of concerned scientists.

This Research would emphasize on the Perceptional basis of students behavior and its impact on Learning/Memory.

\section{Contemporary Literature (Literature Review)}

Prof (Dr) Anchana Lala in her research paper (IOSRJPBS) while attempting to substantiate the prevailing perception that there exists a close Co-relation between Spiritual Mind and Learning capability of a student.

Nilkola khols, James Gorano in their extensive research on effect of Spirituality on learning analyzed and found, empirical evidence to establish the Co-relation.

Kally Anderson on May 212009 in their Research paper tried to established Co-relation between Spirituality of Human Satisfaction and related between. An extensive research on human, in a Hospital in UK, empirically proved that even Dementia has a close Co-relation with spirituality through Qualitative \& quantitive research Design, which directly imply that there exist a relationship between memory and spirituality. 


\section{Objective}

The current research may be a pioneering effort to analyze/understand the relationship between Spiritual effects \& Learning / Memory. From time immemorial, a perception, rather a strong belief exists in India that spiritual \& religious effects makes strong and positive impact on human being. This research would further endeavor and explore with empirical analysis, if the Spiritual / Religious effects can impact the learning capability / memory of a student in anyway.

Privatization in Indian Education Sector has enacted a sea change in the sector. The sector which was being subsidized and run by the Govt.-Monopoly became an Industry, overnight.

There is hardly any doubt that the Indian economy would again recapture its earlier growth momentum from 4th quarter of the current or 1st quarter of next year, the Mid level of Indian market is again poised to grow at a phenomenal pace. It would provide clues to develop such product and services for the BOP segment.

Inclusive growth in an Economy like India, could easily be achieved through BOP marketing. Empowering the BOP consumers would remain a challenge for BOP marketing.

The present study, against the said backdrop would be of special interest from our social perspective.

The present research would focus on the BOP segment of professional institutes and students, whose total courses fees (M.Tech/MBA) ranges between 1-2 lacs per year.

\section{Alternative Perspective/Arguments:}

Prof. A.K. Jaiswal of IIM-A in 2005 stated that in 2002, CK.Prahalad and Stuart Hurt erroneously contended that big MNC's only targeted high - end ( upper-end of the Pyramid) customers ignoring the BOP segment. His major contention was: a. We must avoid undesirable Inclusion and Exclusion in the BOP segment .Inclusion : Products who satisfy the basic needs : health, nutrition, education etc. which can enhance the wellbeing of the BOP consumers Exclusion : Products of mere consumption purpose which do not contribute to the well being of the BOP consumers Failure to provide goods/services which enhance their well-being.

b. Estimate of the World Bank that in 2001, nearly 1.1Billion people earns less than $\$ 1$ daily, and can not be a part of any profitable market segment of a large company. Therefore he argued that Fortune exists only at the Lower Middle and Middle of the Pyramid and not at

the Bottom. * Prof. Karnani(2007) argues that if the objective is to reduce Poverty than the BOP people should not be regarded as Consumers but Producers, as he said that we need to facilitate production by poor and support them to selective consumption for their well being.

He argued that consumption of welfare goods also helps raise their income. Ex: Health insurance reduces the risk and cost of medical treatment reducing the loss of productivity.

Dr. Siamanis in his research in 2009 stated that-Companies should start by getting communities involved in creating, implementing and shaping the business itself. The sense of ownership brings thus, will help ensure that interest these company's products would be wide-spread and sustained. Prof. Cris. went a step further and stated that - "the sense of ownership across the spectrum of Education, Business and Environment is the key to consistent upward growth of an Economy".

\section{Sample Size}

Bundelkhand region in UP, being the locational parameter of the present study, has 6 AICTE approved Technical Institutes and that being the Population and to arrive at a reasonable degree of confidence, we would select 3 larger Institutes and 100 students randomly, from each Institute. We would like to take help of PVASS Pensylvania Value Added System ( Tribune Business News, Washington - Feb'2011. A statistical Method of measuring Influence of School Program o Academic growth of each or a group of students.)

\section{Perspective of the Research Study}

Though the proposed study has Retrospective elements in nature, its findings have all the Prospective and Long - term potentiality for the recession hit Industries in India.

C.K. Prahlad through extensive research on 700 market segments on Social Change, 70 plus Site Visits/Interviews with stake-holders and 1500 customers, reveal that barriers are such as 1) Uncertain CashFlows 2) Changing Demand (confusing Need with Demand) 3) Distribution Challenge. BOP clearly is not for every company even if it is highly motivated. Researchers came up with the following questions:

1. Can we manage Large no of Low margin, Low value transactions

2. Can we work with Informal Markets.

3. Do leaders have a long - term mind set.

4. Can we keep out legacy and Over head Costs.

5. Will Organizational Culture stifle a BOP innovation

But they have concluded that the solution lies in Creating New Business Model. 


\section{Methodology}

Study would be undertaken on the basis of a sample Survey with the help of a Questionnaire. The Questionnaire has been designed in both English and Hindi to elicit the correct response from the respondents, selected randomly. The Researcher decided to undertake a Market - Research Analysis under the concept of MAXIMUM DIFFERENTIAL SCALLING TECHNIQUE (MAX-DIFF) .

This popular and very handy technique was first practiced by Jordan Louviere in 1987 with very simple 6 steps such as :

1. Select Attributes

2. Show it to potential customer

3. Plan the sample survey

4. Respondents to choose BEST - WORST

5. Find out the Score

6. Analyze Data to arrive at conclusion.

We would take the help of basic concept of Conjoint Analysis to obtain estimates of the Main Effects of the Variables. The terminology of describing such conjoint importance in determining the Weights, is in terms of - SCORE/UTILITY. We also intend to analyze the Data on the basis of Percentage and Rank Findings.

Table -1

\begin{tabular}{|l|l|c|c|}
\hline S.No. & & Most & Least \\
\hline 1 & Morning is preferred study time & & $\checkmark$ \\
\hline 2 & Prayer before study help memory & $\checkmark$ & \\
\hline 3 & Religious Mind-good for learning & $\checkmark$ & \\
\hline 4 & Prayer \& learning has no relationship & & $\checkmark$ \\
\hline
\end{tabular}

Table -2

\begin{tabular}{|l|l|l|l|}
\hline S.No. & & Most & Least \\
\hline 1 & Prayer \& learning has close relationship & $\checkmark$ & \\
\hline 2 & Religiousness has nothing to do with learning & $\checkmark$ & \\
\hline 3 & Fresh Mind helps in better learning & $\checkmark$ & \\
\hline 4 & Study at own's will is better for learning & $\checkmark$ & \\
\hline
\end{tabular}

Table-3

\begin{tabular}{|l|l|l|l|}
\hline S.No. & & Most & Least \\
\hline 1 & Study at Night is good for learning & & $\checkmark$ \\
\hline 2 & Religion \& Learning are closely related & & $\checkmark$ \\
\hline 3 & Prayer is good for learning & $\checkmark$ & \\
\hline 4 & Fresh Body \& Mind are necessary for learning & & $\checkmark$ \\
\hline
\end{tabular}

TABULATED RESULT SCORE (Table-4)

\begin{tabular}{|c|l|c|}
\hline SL No & Attribute & Wt.-Av.-Score \\
\hline 1 & Morning is preferred time for Study & 15 \\
\hline 2 & Religious Mind is good for Learning & $40^{*}$ \\
\hline 3 & Prayer before study makes a positive impact on Learning & $25^{*}$ \\
\hline 4 & Fresh Mind helps in Learning & 15 \\
\hline 5 & Prayer and Learning has No Correlation & 5 \\
\hline
\end{tabular}

\section{Conclusion / Findings}

The Final Score/Findings unambiguously indicate: Students really perceive that there is a positive co-relation between Spirituality and Learning.

The $2^{\text {nd }}$ and $3^{\text {rd }}$ attribute with 40 and 25 Score value imply that Religious Mind and Prayer before study are keenly associated with Learning.

\section{Test of Significance / Second Approach}

RANKING AND TEST OF SIGNIFICANCE :

1. Ho - Religious Mind has some degree of Co- Relation with Learning/Memory :

Chi Square Test between Religious Mind and Learning shows : 


\begin{tabular}{|c|c|c|c|}
\hline & \multicolumn{3}{|c|}{ Table -5 } \\
\hline O & $\mathbf{E}$ & $(\mathrm{O}-\mathrm{E})^{2}$ & $(\mathbf{O}-\mathbf{E})^{2} / \mathbf{E}$ \\
\hline 30 & 30.5 & 0.35 & 0.011 \\
\hline 15 & 14.4 & 0.35 & 0.025 \\
\hline 38 & 37.4 & 0.35 & 0.009 \\
\hline 17 & 17.4 & 0.35 & 0.020 \\
\hline
\end{tabular}

Calculated Value $\quad-0.066$

Tabulated Value - 3.84

Degree of Freedom - 1

Analysis of the aforesaid findings shows that Tabulated Value is greater than Calculated Value, directly implying that Ho is accepted, concluding also that Religious mind and Learning has fairly close Co-relation.

2. Ho - Prayer before Study has positive impact on Learning.

Chi Square Test between Prayer and Learning shows:

TABLE - 6

\begin{tabular}{|l|c|c|l|}
\hline $\mathbf{O}$ & $\mathbf{E}$ & $\mathbf{( O - E )}^{2}$ & \multicolumn{1}{|c|}{$(\mathbf{O}-\mathbf{E})^{2} / \mathbf{E}$} \\
\hline 23 & 23.78 & 0.6084 & 0.0255 \\
\hline 18 & 17.22 & 0.6084 & 0.0353 \\
\hline 25 & 28.42 & 0.1169 & 0.4113 \\
\hline 24 & 20.58 & 0.1169 & 0.568 \\
\hline \multicolumn{4}{|c|}{ Total 1.0401} \\
\hline
\end{tabular}

Calculated Value $\quad: \quad 1.0401$

Tabulated Value $\quad: \quad 3.841$

Degree of Freedom : 1

Analysis of the aforesaid findings shows that Tabulated Value is grater than Calculated Value, directly implying that Ho is accepted, concluding also that Prayer and Learning has close Co-relation.

3. Ho - Fresh Mind and Clean Body has a positive bearing on Learning/Memory:

Chi Square Test between Fresh Mind and Learning shows that:

TABLE - 7

\begin{tabular}{|c|c|c|c|c|}
\hline & \multicolumn{4}{|c|}{ TABLE - 7} \\
\hline & 0 & $\mathbf{E}$ & $(\mathrm{O}-\mathrm{E})^{2}$ & $(\mathrm{O}-\mathrm{E})^{2} / \mathrm{E}$ \\
\hline & 30 & 30.6 & 0.0009 & 0.0111 \\
\hline & 5 & 5.85 & 0.7225 & 0.1235 \\
\hline & 4 & 3.12 & 0.7744 & 0.2482 \\
\hline & 10 & 9.15 & 0.7225 & 0.0789 \\
\hline & & & Total & 0.4617 \\
\hline Calculated Value & .461 & & & \\
\hline Tabulated Value : & 4.99 & & & \\
\hline Degree of Freedom: & 2 & & & \\
\hline
\end{tabular}

After analysis, it is found that Tabulated Value is greater than Calculated Value, directly indicating that Ho is accepted, which again proves that Students perceive : Fresh mind has a Positive bearing on Learning.

(NOTE - if distribution of test statistics is an exact $\mathrm{X}^{2}$ distribution then variance of a normally distributed population has a given value, based on sample variance.)

Implication of the Research: The current Research may be a benign and pioneering effort to analytically study behavioral relationship between Student-Perception on Spirituality and their Learning and has an immense potentiality to unravel the Myth about Spiritual effect on human mind in India through scientific and empirical analysis. 


\section{References/Sources}

[1] Fortune at the Bottom of Pyramid

[2] Gurus on People Management

Prof. C.K. Prahalad

Gurus on People Management Prof. Sultan Kermally

Marketing Theory

March / April, 2009

$\begin{array}{ll}\text { Marketing Research } & \text { The Journal of Marketing, Jan, } 84 \\ \text { Consumer Behavior } & \text { Leon Schiffman }\end{array}$

Jan / March , 2009

Leon Schiffman

[8] $\begin{aligned} & \text { Vikalpa }(\mathrm{IIM}-\mathrm{A}) \\ & \text { Decision }(\mathrm{IIM}-\mathrm{K})\end{aligned}$

2003/March

2004/Oct 